\title{
APPRENTICESHIP SYSTEM FOR THE INTERNATIONALIZATION: JALISCO HANDICRAFT PRODUCTION COMPANIES
}

\author{
Tania Elena González Alvarado \\ University of Guadalajara, Mexico \\ E-mail: taniaelena2021@gmail.com \\ Sara González Fernández \\ Universidad Complutense de Madrid, Spain \\ E-mail: sarago@ccee.ucm.es
}

Submission: 6/5/2019 Revision: 9/18/2019 Accept: 10/22/2019

\section{ABSTRACT}

The aim of this article is to analyze learning for the internationalization of craft companies. The study is mixed and is based on a questionnaire, field visits and retrieval of documentary evidence about these companies. The main result is that, self-financing, the application of resources in obtaining raw materials, as well as the adaptation of machinery and equipment to traditional modes of production, have facilitated the internationalization of companies. It is concluded that the learning system promotes self-financing, constant adaptation to change and greater use of the international markets.

Keywords: Financing; production modes; values; custom. 
DOI: 10.14807/ijmp.v11i4.1073

\section{INTRODUCTION}

The companies that manufacture crafts are hardly internationalized. The main limitation lies in the artisanal process. There is the possibility that, when reaching new markets, the demand for the product increases, with the consequence of companies being forced to increase production, and thereby acquire a faster industrial process at a lower cost (GAROFOLI, 1995). In other words, it is possible that internationalization negatively impacts the artisanal process.

For this reason, it is considered relevant to study artisanal companies that have achieved a greater presence in foreign markets. Among the questions that arise when analyzing them, there are the following ones: What elements favor the internationalization of Jalisco handicraft production companies? What factors have facilitated the internationalization of Jalisco handicraft production companies? What role does learning play in all this process?

\section{TURNING OBSTACLES INTO OPPORTUNITIES FOR INTERNATIONALIZATION}

The internationalization implies the ability to transform obstacles into opportunities. Strategists who have the ability to transform scenarios and turn threats into opportunities (LAX; SEBENIUS, 2006) make their companies sustain their advantages. These kinds of competitive advantages are hardly imitable (FERNÁNDEZ; SUÁREZ, 1996; TRUJILLO; VÉLEZ, 2010; FERNÁNDEZ; REVILLA, 2010; MUIÑA; BARAHONA; LÓPEZ, 2008; F-JARDON; MARTOS, 2011).

Many of these advantages are the result of one's own experiences, learning from acts of opportunism and through unfavorable environments. The Apprenticeship system, based on collective action motivations, is important for the opportunity creation (SOSKICE, 1994; SNELL, 1996; HARHOFF; KANE, 1997; SHARPE; GIBSON, 2005; CRAWFORD-LEE, 2016; PULLEN; CLIFTON, 2016; RENDALL; WEISS, 2016; GESSLER; 2019; LALIOTI, 2019; SMITH, 2019; WOESSMANN, 2019).

Learning is envisaged therefore, as a key element to understand the internationalization of companies in conditions in which they would be considered as rather unlikely to internationalize (D’ANGELO; PRESUTTI, 2019; LOVE; MÁÑEZ, 2019). The producer of handicrafts with traditional production methods is no exception. Among the factors that affect the internationalization of the companies producing handicrafts are the following: 
DOI: 10.14807/ijmp.v11i4.1073

- There are only few sources of financing. The financial system responds with higher priority to speculative rather than productive purposes. The high-speed industries are those that get the most financial support, while the traditional, rather slow ones, get very little of it. Finally, the producer of crafts depends almost exclusively on his/her own family of origin and its ways of operating.

- The traditional organization may, at one time, lack the capacity to adapt quickly to changes in the capitalist system.

- There is little or no knowledge about Marketing and Business Management in the handicraft companies, which results in not taking the advantage of the international market, and in missing the opportunities for the company.

These factors do not only correspond to the circumstances faced by Jalisco handicraft production companies but also coincide with those of other regions such as Nicaragua, Peru, India, and Malaysia (FABEIL et al. 2016; JAMIR; SRIDHARAN, 2017; NOVOA; USEDA; MERLO, 2015; RODRÍGUEZ, 2014). In fact, access to credit has been identified as generally difficult at the global level.

The type of available financing and its conditions significantly affect the sustainability of the business (SUBÍA-VELOZ et al., 2018). It is expected, that companies having access to bank credit intensify their exports. However, they do not always access this possibility, or, it turns out that this financing does not necessarily have a positive effect on their activity (STPIERRE; SAKKA; BAHRI, 2018).

The granting of credit to the smaller company depends on at least three conditions: the reliability of the company, the warranty or available pledge and the existence of financial information (MUÑOZ; CÁCERES; AGUILAR, 2014).

The lack of fulfillment of one or more requirements, indicates weakness in the ability to support its funding structure and general creditworthiness. The latter does not only limit the growth of the company, but also gives way to new problems in times of crisis, when other financial resources are scarce and when the ability to demonstrate their repayment capacity is crucial (BORIN; DONATO; SINAPI, 2018).

The smaller the companies, the greater the exclusion of traditional banking financing. Therefore, the sources of financing typical to these companies are based on own funding 
DOI: 10.14807/ijmp.v11i4.1073

sources and non-banking credits (GIMÉNEZ, et al., 2018). It is important to indicate that these last two sources of financing can positively or negatively affect the company.

A lot depends on the entrepreneurs' learning capacity; learning that leads to adaptation to the context and, sometimes, to the transformation of obstacles into opportunities. In the case of companies in the artisan sector that have managed to internationalize, internationalization is identified as an expression of learning, adaptation, and transformation based on the family tradition (Graph 1). Otherwise, these companies would not be able to have a presence in foreign markets.

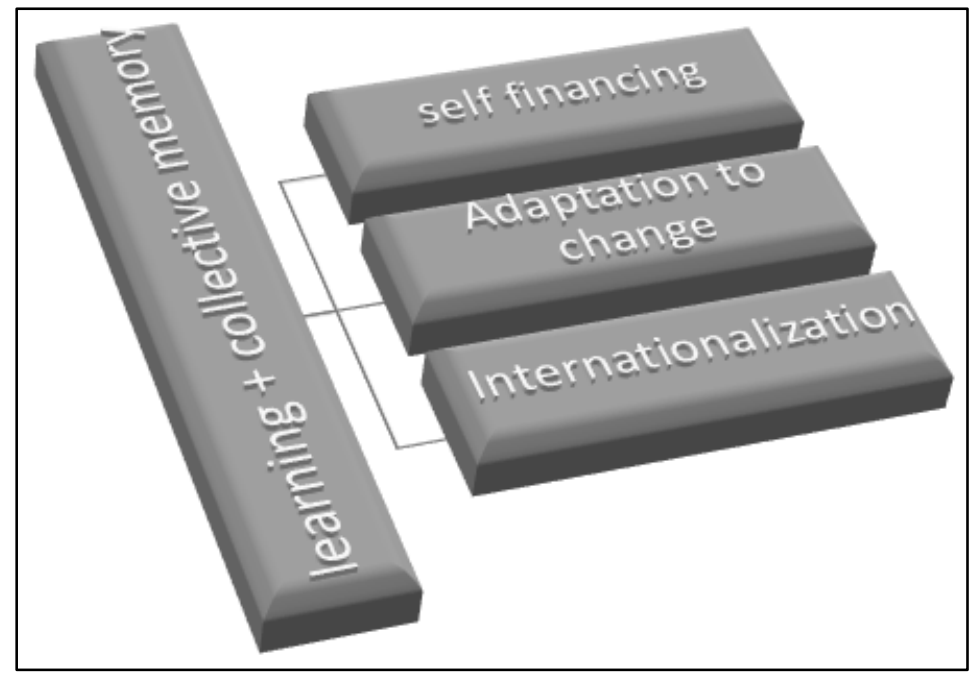

Graph 1: Learning for internationalization based on the obstacles faced by handicraft producers.

Source: own elaboration.

Artisanal companies, based on the ancestral inheritance and accumulated family knowledge, are organizations that learn constantly. There is evidence of strategic vision and capacity for organizational learning in craft companies in Tunisia (AMMAR, 2017). Strategic vision and capacity for organizational learning do not usually explain the internationalization of smaller companies in other economic sectors, but they are strong explanatory factors in the artisan sector.

Important is both the way in which knowledge is transmitted and the understanding of the family in what respects the trade influence. The appropriation of family discourse by younger generations grants a new meaning to their ways of seeing craft work. There is a collective memory that guides the discourse, but finally, each craftsman lives his/her own experience. The motivation of parents and family plays there an important role. It is in the family that a sense of work is formed (FREITAG, 2012). 
DOI: 10.14807/ijmp.v11i4.1073

The innovation processes in low-income countries differ from the models derived from the study of these processes in the richest countries. A study carried out by Fransen and Helmsing (2017) on Indonesian artisanal export companies, found that the incremental innovation of handicraft exporters requires specific absorption capacities, such as linguistic abilities.

This study identified a group of strategists with a high level of own innovation capabilities, a high level of absorption capacity, and a positive effect on supplier innovation. The results show that the dissemination of knowledge is fostered within an emerging system of local innovation (FRANSEN; HELMSING, 2017). All this is true for the artisan sector.

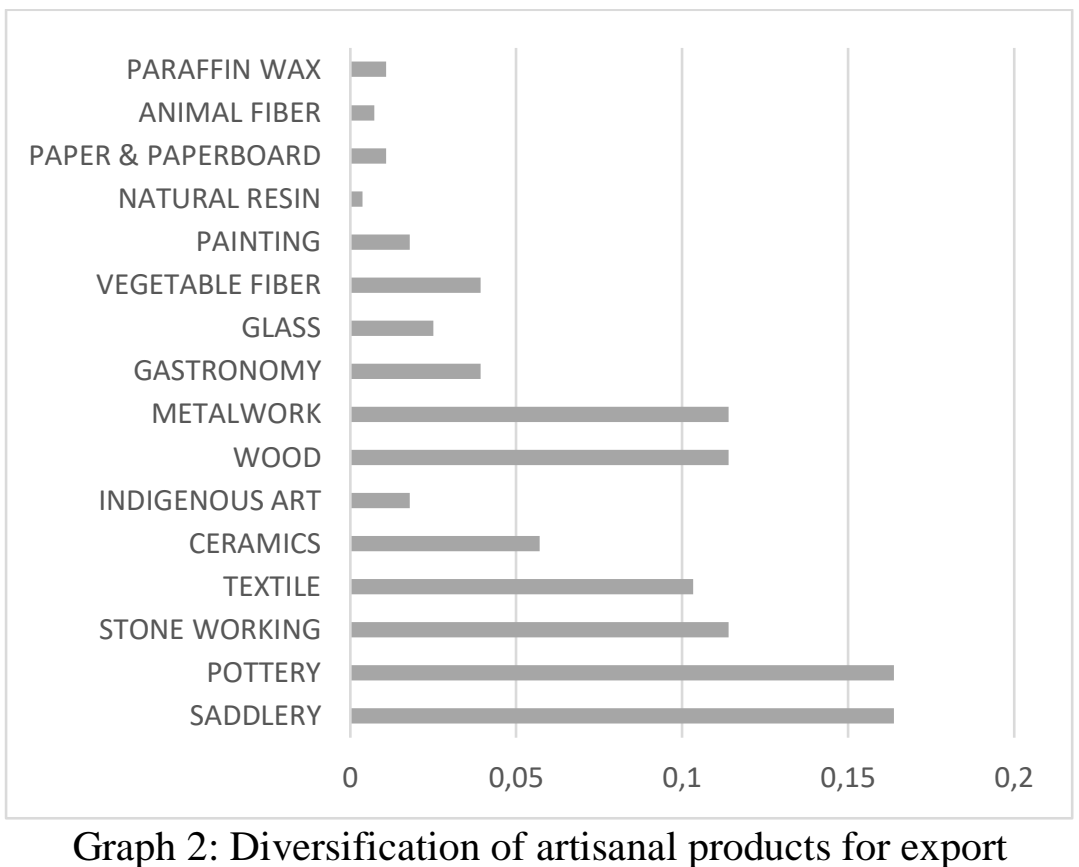

Source: Own elaboration based on the results of the project "Generation of value and international cooperation in the smallest companies in Latin America UDG-CA-484”.

The craftsperson is usually a creative agent. Through production, s/he captures its own perception of reality, its own imagination and its own values. The crafts express the link between the different historical stages. It is possible that this last characteristic explains the high diversity in crafts created in Jalisco (Graph 2).

This diversification is reflected even among the companies that have been internationalized. Each region, each village has its own characteristic handicraft. The variety and quality of its production are being recognized as one of the State's most valuable representations. Artisan work for export purposes requires innovation without expropriating cultural capital. 
DOI: 10.14807/ijmp.v11i4.1073

\section{METHODOLOGY}

The present study is based on the Realism approach (HAUSMAN, 2000). The observed reality is considered more complex than the theory, by means of Popper's falsifiability of science advances (POPPER, 2014).

When the intent is to achieve as much information about a phenomenon as possible (HUSSERL, 2012; HEIDEGGER, 1996), a representative case or a random sample may not be the appropriate strategy. The typical case or the average case usually does not provide the best or the most valuable information (FLYVBJERG, 2006).

Atypical or extreme cases reveal more information because they activate more actors and basic mechanisms of the studied situation. In addition, from an understanding-oriented perspective, it is often more important to clarify the root causes of a particular problem and its consequences, rather than to describe the problem symptoms and the frequency with which they occur.

The characteristics of the case study extend to other cases due to the strength of the explanatory reasoning (YACUZZI, 2005). Random samples will rarely produce this knowledge type; it is more appropriate to select some cases because of their validity (FLYVBJERG, 2006: 45).

In case of working with multiple cases, the replication logic is observed, not the sampling. This logic increases the size of a sample to guarantee a certain degree of certainty. The replication logic is analogous to that of the multiple experiments and leads to the selection of the cases in order to anticipate similar results in all of them or contradictory results, based on predictable reasons (YACUZZI, 2005).

This is the reason why field visits and on-site observation, the semi-structured interview and questionnaires with open questions are used within the project. These tools offer the possibility of recovering details that enrich the phenomenon explanation. The results triangulation, as well as the discussion among experts, is of vital importance for the analysis, too.

The atypical case is an artisan who has achieved international presence without abandoning the traditional process of production that grants the handmade stamp to his/her products. To the extent that they reach the prestige and demand of other regions, they keep clear the renunciation to economies of scale and the company growth. 
DOI: 10.14807/ijmp.v11i4.1073

These artisans have managed to make their production unit competitive internationally despite not very advantageous sector, sustaining international competitive advantages for several decades. Learning based on family structure and values have made it possible and has even allowed them to maintain their financial autonomy.

From a database made up of 10,240 Jalisco handicraft production companies (IAJ, 2017), enterprises that have linked with economic agents from other regions and, therefore, maintain internationalization activities, were identified. Only 2.75 percent of Jalisco handicraft production companies have been internationalized. This percentage is represented by 282 companies. In comparison with the more than ten thousand Jalisco handicraft companies and, according to the sector in which they operate, they are considered an atypical case.

This companies' group should be exhaustively studied because it allows contribution to the internationalization theory. Particularly, in sectors in which the capitalist system and global value chains seem to go against international competitiveness, given the nature of their production.

\section{RESULTS AND DISCUSSION}

Family values have contributed to the survival of artisanal production, regardless of the family's economic situation. The tradition rooted in the core of the family and the vocation of its members lead to a situation where the production has not been industrialized, replaced or eliminated. In this way, the family tradition allows the existence of handicrafts.

The oral transmission of family memories to the new generations and the internalized discourse on family tradition generate a positive vision of the trade (FREITAG, 2015). Cuevas (2007) considers that poverty has also contributed to its existence, however this opinion differs from this document conclusions.

As in the case of other economic activities, there are different reasons why people are involved in craft production: vocation, circumstances, search for an economic income, among others. The market, art, tradition, quality, and identity are factors that attract the demand for handicrafts (GUEVARA, 2008).

In Tlaquepaque, Mexico there are craft designers who can are distinguishable due to their originality and high quality. These two badges lead to the international recognition of their crafts. There are also craftsmen who are dedicated to the imitation of handmade pieces produced with low quality and low prices. 
DOI: 10.14807/ijmp.v11i4.1073

The latter generates strictly commercial relationships with international buyers, mainly Americans. Foreign buyers follow business conduct rules very strict and orderly. Commercial asymmetries encourage distrust in quality as well as lack of knowledge about the supplier (CARCAMO 2011).

Tlaquepaque produces original art that is marketed at high prices. This locality is defined by its infrastructure and architecture (streets, roads, houses, buildings, churches of colonial and classic style), in addition to restaurants and hotels that all together make the attraction of national and foreign tourists more intense. (CARCAMO, 2011)

The National Microentrepreneur Financing Program in México promotes supporting tools integrated by microcredits, accompanied by training and incubation of productive activities. This program helps to start and consolidate various business deals, including Mexican crafts. This seeks to improve the living conditions and well-being of the communities of artisan microentrepreneurs (SE, 2016). However, there are few artisans who come to make use of this type of financing. Most of them prefer self-financing or resort to informal sources derived from their own contact networks.

An important challenge for the artisan is to separate him/herself from the informal economy because the latter facilitates the sustainability of the business. Most of those who have gone from informality to formality, have been attracted by the opportunity to internationalize. Unfortunately, those who do not opt for such a transition usually depend on intermediaries that undermine the benefits obtained by sales abroad.

The location of points of sale in tourist areas leads to crafts being acquired by foreigners and, through migratory flows derived from tourism, taken to other regions. There are also cases in which the foreign entrepreneur comes to the door of the workshop for the acquisition of handicrafts. These last two situations encourage the existence of a large number of artisans in the informal economy.

The Jalisco local learning system reflects the Pre-hispanic (in sense of pre-institutional) heritage. This occurs when knowledge is transmitted from parents to children rather than by institutions outside family. Oral transmission is essential for learning. This heritage is combined with the colonial heritage.

The learning system is strengthened through workshops and self-learning. Higher education courses taken at national and/or foreign universities are the exception, but they also enrich the local learning system. This mixture of different learning sources does not dilute the 
DOI: 10.14807/ijmp.v11i4.1073

family inheritance. This heritage is essential for the artisan conviction to continue with what he/she considers his/her roots. Roots that are proudly exhibited at international events, specialized magazines and in galleries near the workshop.

The learning system encourages novel artisan training. Almost always the apprentices are formed within the same workshop. Thus, the artisan is the teacher who, in teaching the new generations, conserves collective knowledge. Production secrets, lived experiences and sensitivity to creating unique figures become a resource for the handicraft production companies; but it is also a heritage that is hardly shared with people outside of family.

The concept of family extends beyond the consanguineous ties to include the workshop members that over the years have been key personnel to achieve the artisan (also internationalization) goals. Graph 3 shows the learning system in the 282 exporting companies. Family inheritance is the most frequent form. Second is the workshop and, third, self-learning. Internationalization is difficult without considering family ties.

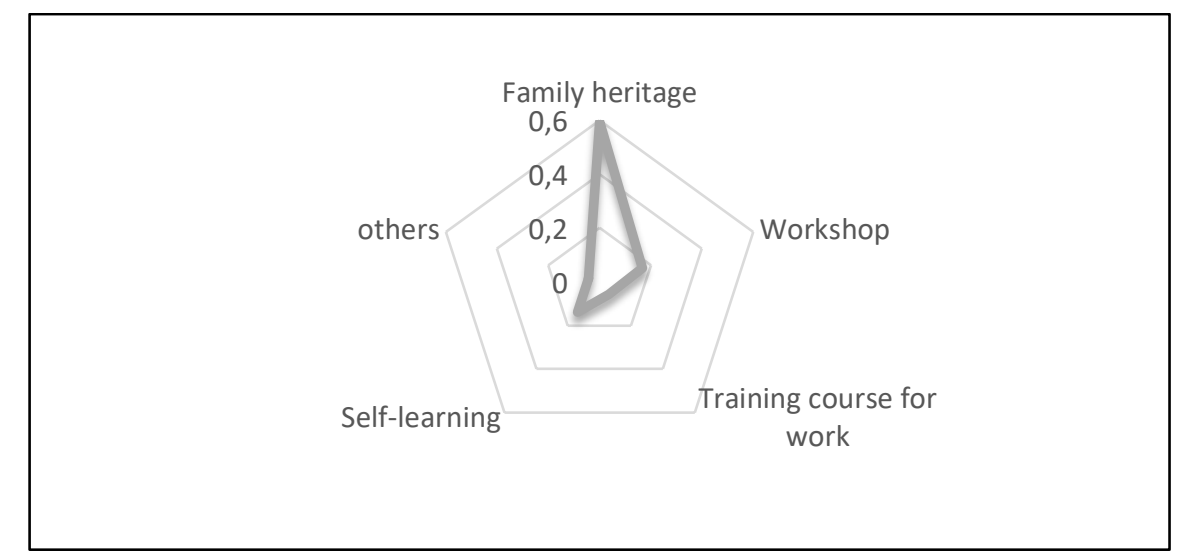

Graph 3: Apprenticeship system in craft exporting companies.

Source: Own elaboration based on the results from the project "Generation of value and international cooperation in the smallest companies in Latin America" UDG-CA-484.

The family of artisans uses the following strategies to achieve their permanence and stability in the artisan trade: artisan organizations, craft contests, and virtual spaces (FREITAG, 2012).

The work tools usually vary a lot. It is not a representative sector for the development and application of advanced technology. It is a sector that lends itself to the creation of its own tools; or in some cases, to the adaptation of tools and industrial machinery (Graph, 4). 


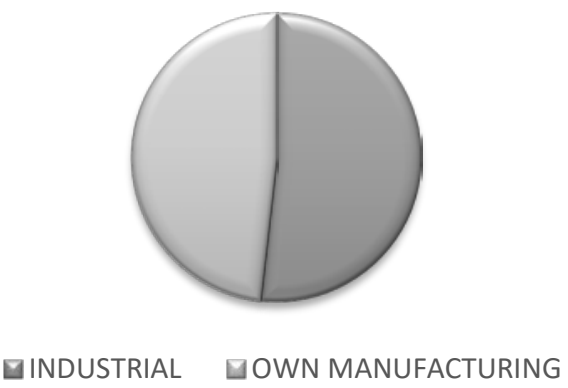

Graph 4: Tools used by the handicraft production companies.

Source: Own elaboration based on the results from the project "Generation of value and international cooperation in the smallest companies in Latin America" UDG-CA-484.

The level of economic informality in the sector is no surprise. This economic activity precedes capitalism (Graph, 5). However, only companies in the formal economy are linked to economic agents abroad. This requires the fiscal formalization of the craft manufacturing companies. Thus, these companies issue invoices when foreign client makes a purchase (direct internationalization).

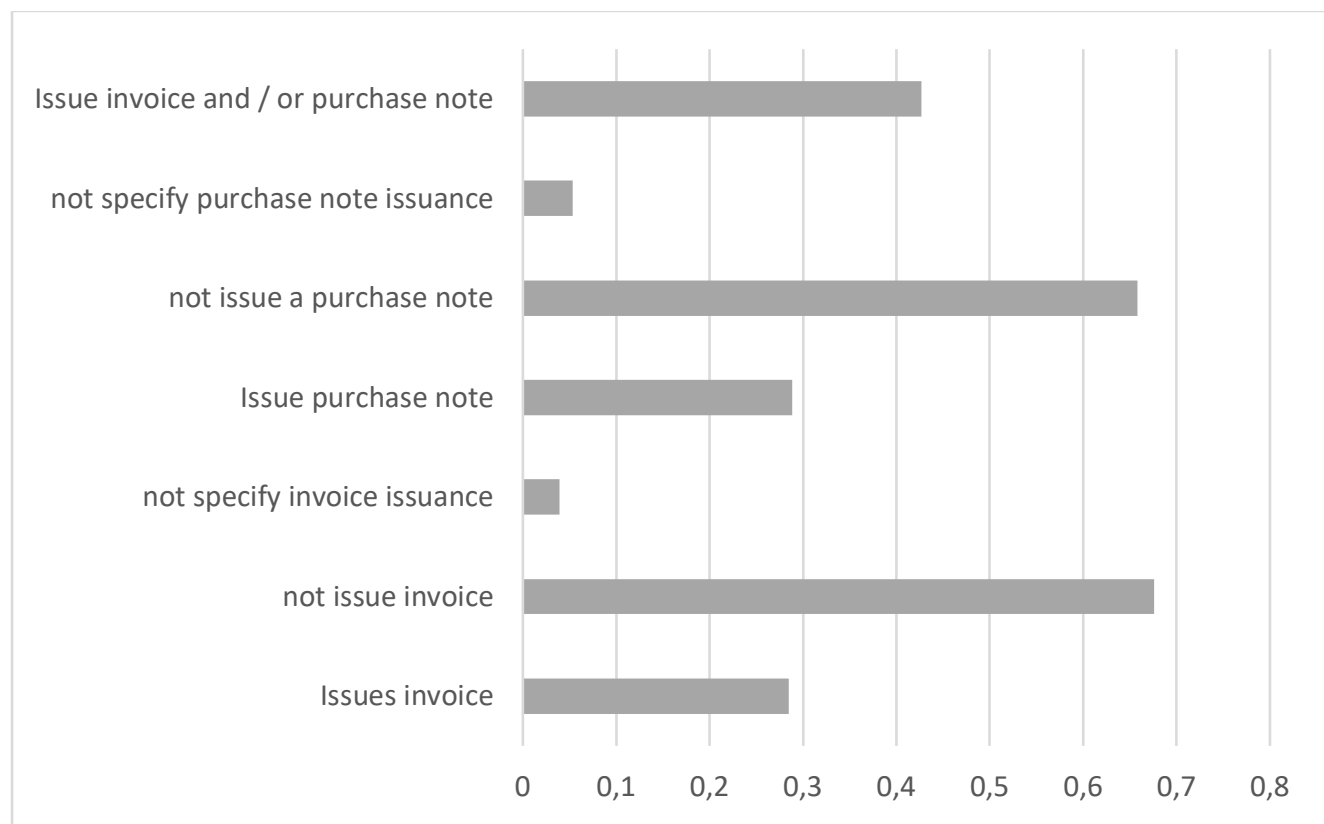

Graph 5: Economic formality level in the handicraft production companies. Source: Own elaboration based on the results of the project "Generation of value and international cooperation in the smallest companies in Latin America" UDG-CA-484.

Meanwhile, they can also issue purchase notes for sales abroad through another local company (indirect internationalization). However, companies that have reached a high level of internationalization issue invoices for each transaction $(28.46 \%$ of the companies studied, Graph 5). 
DOI: 10.14807/ijmp.v11i4.1073

It is possible that the degree of internationalization has an indirect relationship with the degree of economic informality of the company. If the internationalization level is low, then the informal level is high. If the internationalization level is high, then the informal level is low.

The company maintains a size small enough to preserve the closeness between the teacher and the apprentice. A larger size transforms the teacher into a manager or administrator, and the apprentice into an employee. The growth of the company beyond these limits has a negative impact on both the product quality and the work environment.

In principle, it is committed to quality craftsmanship that finds an international market willing to pay a relatively expensive price. The trend towards greater growth in terms of outreach and higher sales is moving away from the interest of internationally successful artisans.

The constant growth in production leads to the end of the activity as an artisan. For this reason, it is possible that an increase in sales is due to the fact that the product tends to increase its value, and it is not necessarily caused by an increase in the quantity of the units produced. (Graph 6)

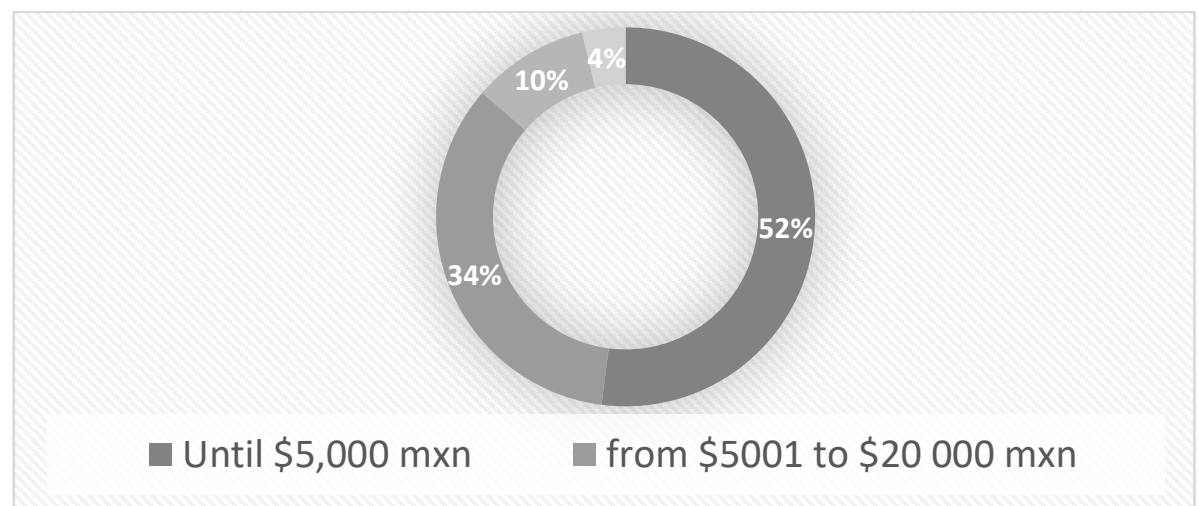

Graph 6: Monthly sales of handicraft production companies.

Source: Own elaboration based on the results of the project "Generation of value and international cooperation in the smallest companies in Latin America" UDG-CA-484.

The craftsman who operates permanently in an international environment opts for the demand for his product leading to an increase in price rather than an increase in the units produced.

This gives greater sustainability to crafts. Only 4 percent is getting monthly sales greater than 50,000.00 Mexican pesos. It is considered that this group represents artisans with the highest international prestige. They maintain a website with a detailed catalog of the pieces 
DOI: 10.14807/ijmp.v11i4.1073

they produce, the art expressed makes them unique, the quality in the production process precedes the quantity.

52 percent of artisans earn a monthly income of up to 5,000.00 per month. This group corresponds to the craftsmen who carry out a few international activities. They focus more on the local market, in which they opt for the flows of international tourism, making agents from other regions come to demand their crafts. They locate their workshops at points near historic sites and craft markets, sites with greater affluence of people interested in knowing and obtaining a regional product.

The Mexican magical towns, the local government investment, and the tourism influx contribute to the sales of artisans. There is no entrepreneur in the study group whose location is on the periphery of the cities where it is located. On the contrary, its galleries and workshops are located in the most central area of the towns in which they are located.

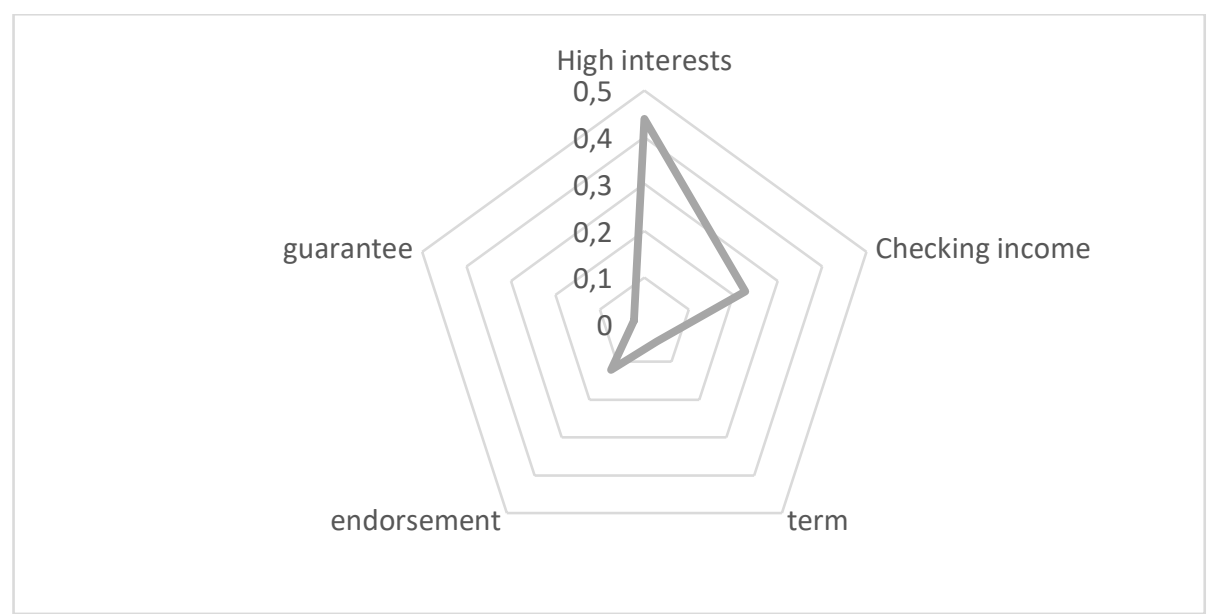

Graph 7: Obstacles to accessing financing.

Source: Own elaboration based on the results of the project "Generation of value and international cooperation in the smallest companies in Latin America" UDG-CA-484.

The financing offered by credit institutions is practically unnecessary (Graph 7). From a financial perspective, it is important to point out that high interest rates are not a cause of credit being inaccessible; rather, it shows that credit is not tailored to that productive sector. Requiring a higher interest rate than the entrepreneur can bear through applying the business activity resources, makes the credit unnecessary. Probably the causes would also include the thorough requirements covering the bank risk perspective.

Any connoisseur of credit knows that even when the information for a loan is fulfilled, it can be rejected because it is not consistent with the risk assumed by the creditor. The same 
ISSN: 2236-269X

DOI: 10.14807/ijmp.v11i4.1073

also happens with the terms of financing. The result, these companies turn to other external sources of financing (Graph 8). Few have required financing from credit institutions (Graph 9).

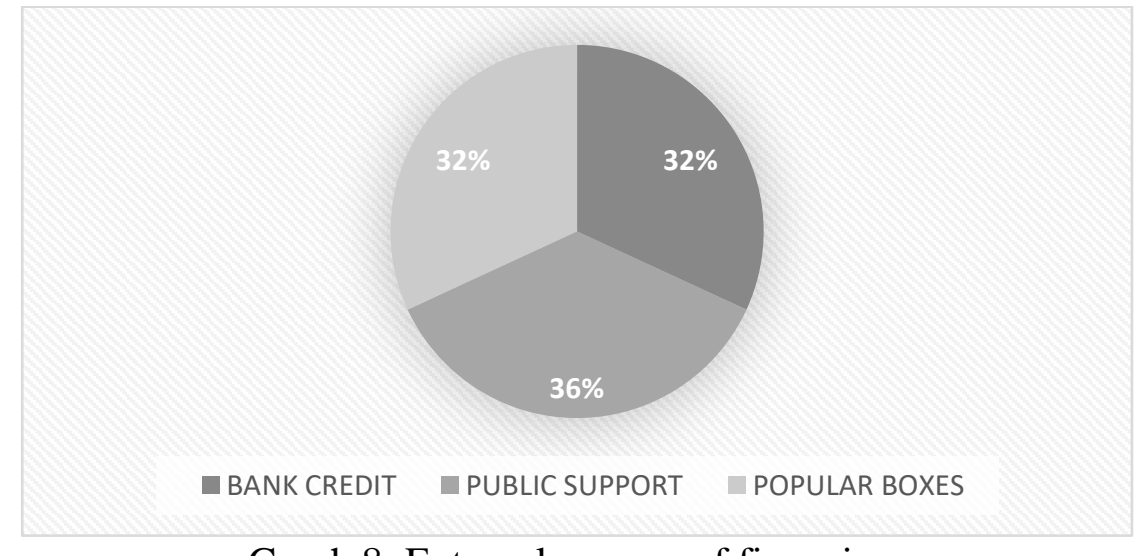

Graph 8: External sources of financing.

Source: Own elaboration based on the results of the project "Generation of value and international cooperation in the smallest companies in Latin America" UDG-CA-484.

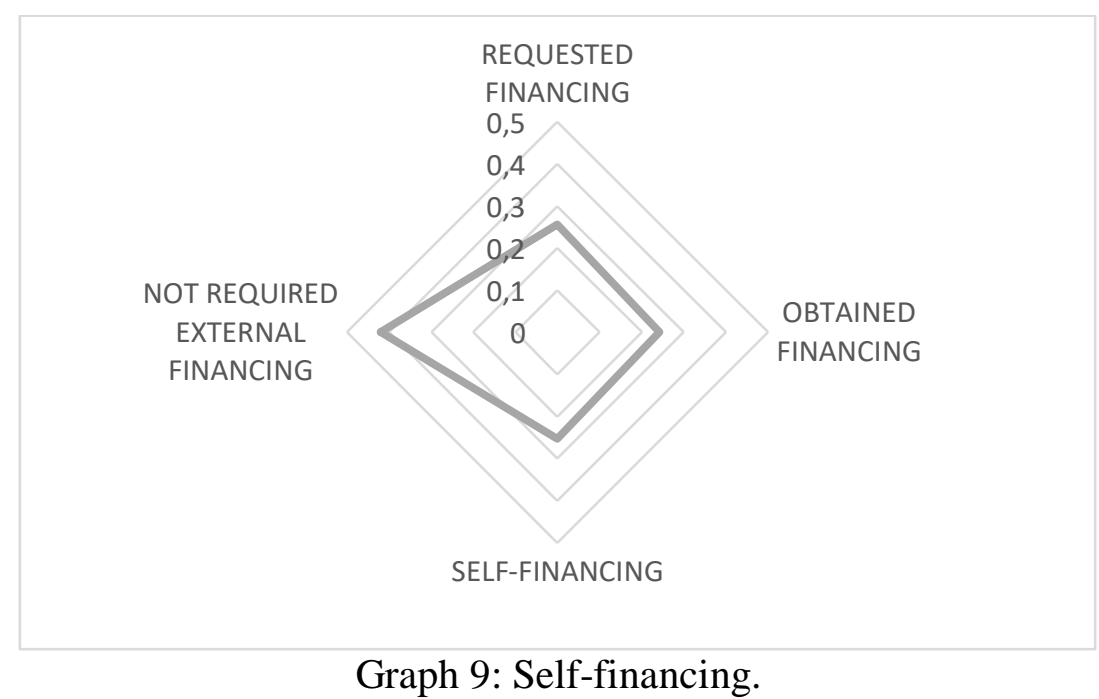

Source: Own elaboration based on the results of the project "Generation of value and international cooperation in the smallest companies in Latin America" UDG-CA-484.

The financing is achieved thanks to relatives and acquaintances. The members of the family form a supportive network that financially help the activity. Family finances are often combined with self-financing. Financial resources are applied to acquisition of the raw material for production rather than for purchasing machinery and equipment. Only a small percentage is interested in remodeling the workshop (Graph 10).

Functional obsolescence (Cervera, 2013) seems not to be present in this type of company. The number of materials, molds, tools, drying pieces or pieces in process occupy a large part of the space devoted to the production of handicrafts. (Freitag, 2012) 


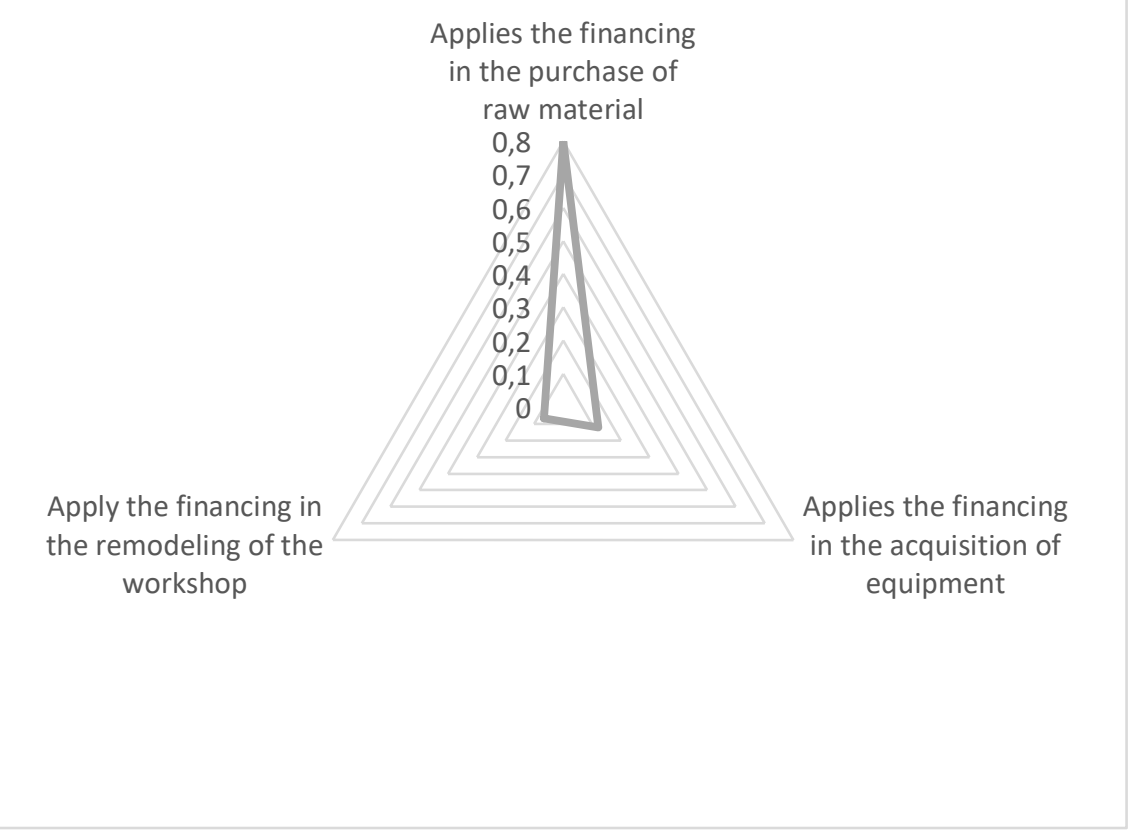

Graph 10: Application of financial resources

Source: Own elaboration based on the results of the project "Generation of value and international cooperation in the smallest companies in Latin America" UDG-CA-484.

\section{CONCLUSION}

The family inheritance allows the existence of companies that produce handicrafts. Collective memory and learning open the way to internationalization without abandoning the artisan craftsmanship. Learning is combined with training of artisan strategists who cover the roles of the creative and entrepreneurial agents to transform obstacles into opportunities. In this way, the learning system of these companies encourages self-financing, constant adaptation to change and greater use of the international market.

\section{REFERENCES}

AMMAR, F. (2017) The growth factors of Tunisian handicraft small and medium-sized enterprises (SMEs): Towards an integration of cognitive approaches. International Journal of Technology Management \& Sustainable Development, v. 16, n. 3, p. 229-248.

BORIN, E.; DONATO, F.; SINAPI, C. (2018) Financial Sustainability of Small-and Medium-Sized Enterprises in the Cultural and Creative Sector: The Role of Funding. In: INNERHOFER E.; PECHLANER H.; BORIN E. (Eds) Entrepreneurship in Culture and Creative Industries. Cham: Springer, p. 45-62.

CARCAMO, M. (2011) El encuentro de dos culturas: caso de estudio sobre los consolidados en el distrito artesanal en Tonalá y Tlaquepaque, Jalisco, México”. In ESTRADA, S.;

MARTÍN, M.; MOLINA, R. (coord.) Diversidad Cultural y Colaboración

Sociotecnológica, p. 36-54. 
CERVERA, J. (2013) El declive de la arquitectura moderna: deterioro, obsolescencia, ruina. Palapa, v. 4, n. 2, p. 29-43.

CRAWFORD-LEE, M. S. (2016) Towards a sustainable apprenticeship system. Higher Education. Skills and Work-Based Learning, v. 6 n. 4, p. 324-328.

CUEVAS, A. (2007) Turismo y consumo artesanal en Tlaquepaque, Jalisco, México en tres etapas del siglo XX. Estudios sobre las culturas Contemporáneas, v. 62, n. 26, p. 103-125.

D’ANGELO, A.; PRESUTTI, M. (2019) SMEs international growth: The moderating role of experience on entrepreneurial and learning orientations. International Business Review, v. 28, n. 3, p. 613-624.

F-JARDON, C.; MARTOS, M. (2011) Un método para determinar competencias distintivas en pequeñas y medianas empresas. Revista de Administração da Universidade Federal de Santa Maria, v. 4, n. 2, p. 195-214.

FABEIL, N.; MARZUKI, K.; RAHIM, I.; Pazim, K.; Langgat, J. (2016) Exploring Factors for Small Business Start-up and Commercialization: Qualitative Evidence from Handicraft Entrepreneurs in Sabah, Malaysia. Journal for Sustainable Tourism Development, v. 5, n. 1, p. 13-31.

FERNÁNDEZ, Z.; SUÁREZ, I. (1996) La estrategia de la empresa desde una perspectiva basada en los recursos. Revista Europea de Dirección y Economía de la empresa, v. 5, n. 3, p. 73-92.

FERNÁNDEZ, Z.; REVILLA, A. (2010) Hacer de la necesidad virtud: los recursos de las pymes. Economía industrial, n. 375, p. 53-64.

FRANSEN, J.; HELMSING, A. (2017) Absorptive capacity as a mediator: Innovation of handicraft exporters in Yogyakarta, Indonesia. Tijdschrift voor economische en sociale geografie, v. 108, n. 6, p. 737-752.

FREITAG, V. (2015) Sobre familias de artesanos y sus artesanías:¿ Cómo seguir siendo artesano en Tonalá, Jalisco?. Vínculos. Sociología, análisis y opinión, n. 5, p. 31-49.

FREITAG, V. (2012) Memorias del Oficio Artesanal: un estudio con tres familias de artesanos de Tonalá, Jalisco. Thesis (PhD in Social Sciences). Guadalajara: Centro de Investigaciones y estudios Superiores en Antropología Social.

GAROFOLI, G. (1995) Desarrollo económico, organización de la producción y territorio. In A. VÁZQUEZ; G. GAROFOLI, (Eds). Desarrollo económico local en Europa, Madrid: Colegio de Economistas, p. 53-71.

GESSLER, M. (2019). Concepts of Apprenticeship: Strengths, Weaknesses and Pitfalls. In S. MCGRATH; M. MULDER; J. PAPIER; R. SUART (Eds). Handbook of Vocational Education and Training: Developments in the Changing World of Work, Cham: Springer. p. 1-34.

GIMÉNEZ, M.; BÚA, M.; SESTAYO, R.; LÓPEZ, S. (2018) Financiación con microcréditos en micro y pequeñas empresas uruguayas. REICE: Revista Electrónica de Investigación en Ciencias Económicas, v. 5, n. 10, p. 15-29.

GUEVARA, M. (2008) Los artesanos de Tlaquepaque y sus saberes como parte del Patrimonio Cultural Intangible del Estado de Jalisco. Desarrollo. Mexico: Cámara de Diputados.

HARHOFF, D.; KANE, T. (1997) Is the German apprenticeship system a panacea for the US labor market?. Journal of Population Economics, v. 10, n. 2, p. 171-196. 
HAUSMAN, D. (2000) El realismo crítico y las teorías de sistemas abiertos. Argumentos de Razón Técnica, n. 3, p. 61-92.

HEIDEGGER, M. (1996) Being and time: A translation of Sein und Zeit. New York: State University of New York Press.

HUSSERL, E. (2012) Ideas: General introduction to pure phenomenology. London: Routledge.

JAMIR, I.; SRIDHARAN, P. (2017) Government and Institutions’ Role in Promoting MicroEnterprises: A Study among Handicraft Entrepreneurs in Dimapur District, Nagaland.

Entrepreneurship Education. Singapore: Springer, p. 367-90.

LALIOTI, V. (2019) Training-related dimensions of apprenticeship programs in crisis-ridden Greece: an exploratory study. International Journal of Training and Development, v. 23, n.1, p. 51-68.

LAX, D.; SEBENIUS, J. (2006) 3-D Negotiation: Powerful tools to change the game in your most important deals. Boston: Harvard Business Press.

LOVE, J.; MÁÑEZ, J. (2019) Persistence in exporting: Cumulative and punctuated learning effects. International Business Review, v. 28, n. 1, p. 74-89.

MUIÑA, F.; BARAHONA, E.; LÓPEZ, J. (2008) La complejidad del conocimiento y el sostenimiento de las ventajas competitivas. Cuadernos de Economía y Dirección de la Empresa, v. 11, n. 37, p. 7-32.

MUÑOZ, Y.; CÁCERES, L.; AGUILAR, J. (2014) Factores relevantes considerados en el financiamiento gubernamental dirigido a las pymes Yucatecas. Red Internacional de Investigadores en Competitividad, v. 8, n. 1, p. 2824-43.

NOVOA, A.; USEDA, W.; MERLO, N. (2015) Estructura de costos de una PYME artesanal dedicada al área de bordado en el Departamento de Masaya. Revista Universidad y Ciencia, v. 8, n. 12, p. 65-75.

POPPER, K. (2014) Conjectures and refutations: The growth of scientific knowledge. London: Routledge.

PULLEN, C.; CLIFTON, J. (2016) England's apprenticeships: assessing the new system. London: Institute for Public Policy Research/JP Morgan Chase New Skills at Work Programme.

RENDALL, M.; WEISS, F. (2016) Employment polarization and the role of the apprenticeship system. European Economic Review, n. 82, p. 166-186.

RODRÍGUEZ, L. G. (2014) Lecciones aprendidas sobre adopción de TIC en PYMES: la experiencia del FOMIN/BID en América Latina. Caracas: Fundación Telefónica Venezuela.

SE. (2016) Apoyo a los proyectos productivos de los artesanos. Mexico: Secretaría de Economía.

SHARPE, A.; GIBSON, J. (2005) The apprenticeship system in Canada: Trends and issues (No. 2005-04). Ottawa: Centre for the Study of Living Standards.

SMITH, E. (2019) A small study of big issues in apprenticeship: Companies' apprenticeship management practices in Australia. Contemporary Apprenticeship Reforms and

Reconfigurations, v. 35, p. 55-59. 
DOI: 10.14807/ijmp.v11i4.1073

SNELL, K. D. (1996) The apprenticeship system in British history: the fragmentation of a cultural institution. History of Education, v. 25, n. 4, p. 303-321.

SOSKICE, D. (1994) Reconciling markets and institutions: The German apprenticeship system. In Training and the private sector: International comparisons. Chicago: University of Chicago Press, p. 25-60.

ST-PIERRE, J.; SAKKA, O.; BAHRI, M. (2018) External Financing, Export Intensity and Inter-Organizational Collaborations: Evidence from Canadian SMEs. Journal of Small Business Management, v. 56, n. S1, p. 68-87.

SUBÍA-VELOZ, R.; BARZAGA-SABLÓN, O.; NEVARES-BARBERÁN, V. (2018) El financiamiento de las medianas empresas en la provincia Manabí, Ecuador. Ciencias Holguín, v. 24, n. 1, p. 57-69.

TRUJILLO, M.; VÉLEZ, R. (2006) Responsabilidad ambiental como estrategia para la perdurabilidad empresarial. Universidad \& Empresa, v. 5, n. 10, p. 291-308.

WOESSMANN, L. (2019) Facing the life-cycle trade-off between vocational and general education in apprenticeship systems: An economics-of-education perspective. Journal for Educational Research Online/Journal für Bildungsforschung Online, v. 11, n. 1, p. 3146.

YACUZZI, E. (2005) El estudio de caso como metodología de investigación: teoría, mecanismos causales, validación (No. 296). Buenos Aires: Universidad del CEMA. 